O. Petrenko, B. Liubarskiy, V. Pliugin

\title{
DETERMINATION OF RAILWAY ROLLING STOCK OPTIMAL MOVEMENT MODES
}

\begin{abstract}
Purpose. To develop a methodology for simulating of an electromotive railway rolling stock in terms of power-optimal modes on a track with a given profile and a set motion graph. Methodology. We have used combined genetic algorithm to determine optimum modes of an electromotive railway rolling stock motion: a global search is performed by a genetic algorithm with a one-point crossover and roulette selection. At the final stage of the optimization procedure we have used Nelder-Mead method for the refinement of the optimum. Results. We have obtained that traction motor on a tramcar, while driving on a fixed site, has an excessive power of the cooling system. Its using only in the considered area allows to modernize the cooling system in the way of its power reducing, which in turn provides an opportunity to increase the overall efficiency of the electromotive railway rolling stock. Originality. For the first time, we have obtained the train motion equation in the program-oriented form. This allows to use it for determination of electromotive railway rolling stock optimal control laws according to the Hamilton-Jacobi-Bellman method. Practical value. We have made the computer program to determine optimum modes of an electromotive railway rolling stock motion. The experimental studies of program results for the track section have confirmed the adequacy of the model, which allows to solve the traffic modes optimization problem for the tram track sections and increase the overall efficiency of the electromotive railway rolling stock. References 19, figures 3.
\end{abstract}

Key words: electromotive railway rolling stock, genetic algorithm, cooling system, traction motor, tramcar, control laws, optimization problem, efficiency.

Разработана методика моделирования движения асинхронного тягового двигателя при движении электроподвижного состава по энергооптимальным режимам на участке пути с заданным профилем и установленным графиком движения. Определены оптимальные режимы движения электроподвижного состава на основе метода Гамильтона-Якоби-Беллмана. Определение режимов работы тягового привода предложено проводить заранее на основании решения задачи условной оптимизации его режимов. Определение оптимальных режсимов работы тягового привода было проведено на основе комбинированных методов условной минимизации функции. Использование предлагаемой методики позволяет повысить общий КПД электроподвижного состава. Библ. 19, рис. 3

Ключевые слова: электроподвижной состав, генетический алгоритм, система охлаждения, тяговый двигатель, вагон трамвая, законы управления, проблема оптимизации, коэффициент полезного действия.

Introduction. The processes of energy conversion in traction electromechanical converters (traction motors) relate to constant losses in different elements of its construction. The most of power loss are caused by physical processes of energy conversion [1-5]. The temperature of the traction motors design parts increases with the operating time and may exceed the permissible design limitations. This is especially true for the windings insulation temperature, which is limited to the thermal class of applied insulation [2-5]. To reduce the temperature on traction motors, cooling systems that increase the efficiency of the heat transfer of the motor construction components are used.

However, cooling systems need additional costs for their efficient work, which in turn reduces the efficiency of the electric vehicle in general. Thus, the creation of an efficient cooling system for electromotive vehicles is one of the most important scientific and technical problems solved by many leading scientists in the field of railway transport [1-5].

The following ways are possible to solve this problem: reduction of losses in the elements of traction motors design and increase of efficiency of the cooling system. Optimization of traction motors designing processes, which is common in most enterprises of leading electrotechnical manufacturers, allows to create traction motors optimal by their efficiency [1].

However, the modes of their operation on the electromotive railway rolling stock (ERRS), which moves at different speeds and under different load conditions, significantly reduce its overall efficiency [1, 6-12].
Determination of optimal motion modes by energy consumption criteria can improve the efficiency of the cooling system of traction motors [1, 6-12].

The paper considers the solution of this problem for the most common motors in production now - an asynchronous traction motors (ATM) on the base of Hamilton-Jacobi-Bellman method.

The aim of the paper to improve the methodology of an electromotive railway rolling stock simulation in terms of power-optimal modes on a track with a given profile and a set motion graph.

The task of optimizing of the traction drive modes. The basic states of the simulation method for the electromotive rolling stock in terms of power-optimum modes at the track with a given profile and a fixed motion graph and initial developments were described in papers $[17,18]$. In this paper we present the results of further authors researches that were begun in previous works.

The determination of the ATM-SVI circuit efficiency based on the approaches proposed in the works $[1,13]$ is carried out, which include the following: to solve the problem of determining the optimal modes of the traction drive, four problems of the conditional optimization of the parameters of the traction drive must be solved (in acceleration modes $U_{o p}=1$, regenerative braking mode $U_{o p}=5$, maintaining mode of a given movement speed $U_{o p}=2.3$ ).

The efficiency of the traction drive in a certain mode of its work will be evaluated according to the criterion of maximum of its efficiency, subject to compliance with the requirements imposed by the operation modes. 
Therefore, the task of determining the efficiency of the traction drive is to find the extremum of the drive factor function.

The efficiency of the traction drive (Fig. 1) can be given under the next equation:

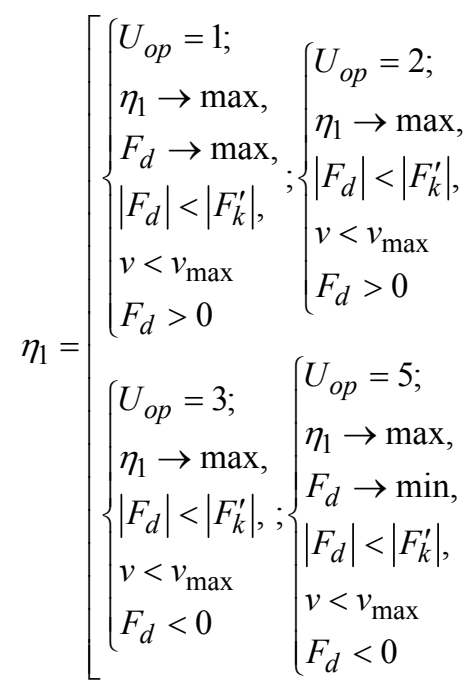

where $\eta_{1}$ - efficiency of the asynchronous traction motor (ATM) circuit - standalone voltage inverter (SVI), $U_{o p}$ the operation mode of an electromotive railway rolling stock (ERRS), $F_{d}$ - traction or braking force created by ERRS, $F_{k}^{\prime}$ - limitation for engagement force of wheelrail contact, $v$ - railway rolling stock speed, $v_{\max }$ constructive movement speed. $U_{o p}=4$ - outburst mode is an idle mode, so it is not considered in determining of drive efficiency.

For each of these tasks, it is necessary to consider two modes: the use of single-time or spatial-vector pulsewidth modulation (PWM). The mode of acceleration and regenerative braking are similar. Apply the method of vector objective functions proposed in $[1,14]$. As a target function for the acceleration mode, we select a vector function with the next parameters:

$$
F_{c 1}=\left[\begin{array}{l}
1-\eta_{1} \rightarrow \min , \\
-F_{d} \rightarrow \min ,
\end{array}\right] .
$$

The first component is chosen in such way that when it is minimized, the maximization of the efficiency of the traction drive can be obtained.

For regenerative braking mode, the vector target function has the form:

$$
F_{c 5}=\left[\begin{array}{l}
1-\eta_{1} \rightarrow \min , \\
F_{d} \rightarrow \min ,
\end{array}\right] .
$$

For a given speed maintaining mode we select as a target function:

$$
F_{c 3}=F_{c 4}=1-\eta_{1} \rightarrow \min .
$$

The value of losses, and hence the efficiency of the drive, can be determined based on the slip of the traction motor, the motor voltage (phase or line) and the rotation speed. Because the operating modes are determined for all motion speeds (ATD rotation speeds), the rotation speed is a predetermined constant given in solving problem of finding the optimal traction drive operation mode.
Thus, the target functions to determine the traction drive optimal operating modes were chosen, which allow to find the optimal traction drive modes when different PWM modes are using.

The general formulation of an optimal control in real time in [13] is described.

Software-oriented model of the ERRS motion. As an optimization method, a combined genetic algorithm was chosen: a global search is performed by a genetic algorithm with a one-point crossover and roulette selection. At the final stage of the optimization procedure, the refinement of the optimum by the Nelder-Mead method is carried out [1, 13-19].

Let us consider the representation of the train motion equation in the program-oriented form, which will allow to use it for determination of the optimal control laws according to the Hamilton-Jacobi-Bellman method.

In this paper, the forces and supports are calculated as follows:

Acceleration force $F_{A}$ (for one time step)

$$
F_{A}=m \frac{v(t)-v(t-t s t e p)}{t \text { step }},
$$

where $m$ - train weight, a conjunction;

$$
a=\frac{v(t)-v(t-t s t e p)}{t \text { step }},
$$

where $a-$ the equivalent constant acceleration, which is subjected to a train at a speed difference $v(t)-v(t-t$ step $)$ in one time step, due to the assumption that for each time step the acceleration is constant and the speed is linearly dependent on the time for each time step.

The main resistance to rolling $F_{r r}$ (for one time step).

Since the velocity is linearly dependent on the time for each transition (time step), the rolling resistance for each time step can be calculated according to the average speed step and is equal to:

$$
v_{\text {avg }}=\frac{v(t)+v(t-t \text { step })}{2} .
$$
will be:

Thus, the main motion resistance for each time step

$$
F_{r r}=a_{r r}+b v_{a v g}+c v_{a v g}^{2},
$$

where $a_{r r}, b, c$-coefficients which for the tram car T-3 VPA with a full load $30000 \mathrm{~kg}$ have the following values: $1500 \mathrm{~N}, 0 \mathrm{~N} \cdot \mathrm{c} / \mathrm{m}$, and $1.5 \mathrm{~N} \cdot \mathrm{c}^{2} / \mathrm{m}$ accordingly.

As a result, the force for ERRS moving on tstep:

$$
F_{\text {tot }}=(1+\gamma) F_{A}+F_{r r}+F_{S}+F_{r k} .
$$

where $F_{s}, F_{r k}$ - resistance forces from the slopes and curves determined by the following equations:

$$
\begin{aligned}
& F_{s}=m g \frac{i}{1000}, \\
& F_{r k}=\frac{c_{r 0}}{R-c_{r 1}} m,
\end{aligned}
$$

where $c_{r 0}, c_{r l}-$ constants, determined by [15]; $R$ - radius of the curve, $i$-slope, $g$ - gravitational acceleration.

The required energy for movement on tstep, considering the limitations and the assumption that the velocity changes linearly over time, using [15] is listed below. 
For the time step from the state $n-1$ to the state $n$, from the equation of equally accelerated motion, the traveled distance can be obtained by equations (13).

$$
\left\{\begin{array}{c}
E=\sum_{t=t s t e p}^{T} \frac{\text { sign }}{\left(\eta_{1}\right)^{\text {sign }}} \mid \begin{array}{l}
(1+\gamma) F_{A}+a_{r r}+ \\
+b v_{a v g}+ \\
+c \cdot v_{a v g}^{2}+\frac{c_{r 0}}{R-c_{r 1}} \cdot m+ \\
+m g \frac{i}{1000}
\end{array} \\
\times \frac{v(t)+v(t-t s t e p)}{2} \cdot t s t e p \\
\left|\begin{array}{l}
(1+\gamma) F_{A}+a_{r r}+b * v_{a v g}+ \\
+c * v_{a v g}^{2}+\frac{c_{r 0}}{R-c_{r 1}} \cdot m+m g \frac{i}{1000}
\end{array}\right| \leq \\
\leq 9.81 k_{s} m \cdot 1000
\end{array} \mid \times\right.
$$

where $k_{s}$ - the coefficient of clutch, which for the tram is $0.16, v_{a v g}-$ average speed per step.
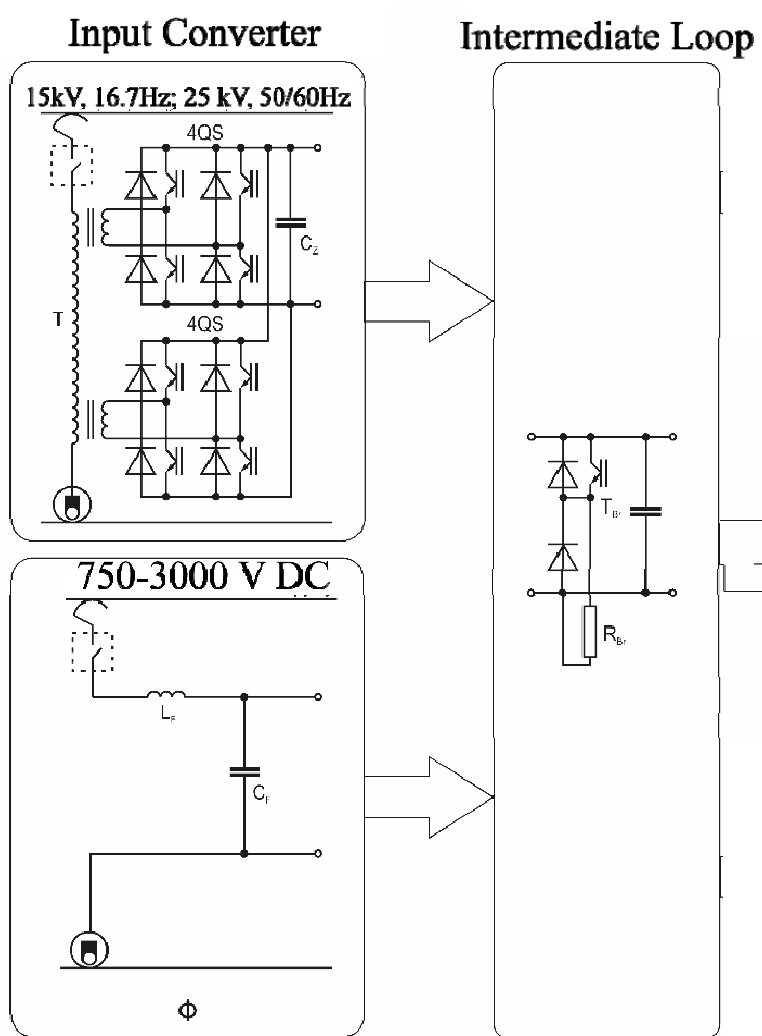

Expression (14) gives the final position of the train for transfer, when the initial position, the initial and final velocities are known, as well as the value of the time step.

Thus, the resulting equations $(12-14)$ allow to improve the simulation method of the electromotive rolling stock in terms of energy optimum modes.

The solution of the traffic modes optimization problem for the track section from the tram depot «Saltovske» to the turning circle of 602 district in Kharkiv and in the reverse direction was carried out. The results of solving the traction problem with tram traffic in

$$
\begin{gathered}
\Delta x_{n}=v_{n-1} \Delta t_{n}+\frac{1}{2} a_{n} \Delta t_{n}, \\
\Delta x_{n}=v_{n-1} * \Delta t_{n}+\frac{1}{2} \frac{v_{n}-v_{n-1}}{\Delta t_{n}} \Delta t_{n}^{2} \Rightarrow \\
\Delta x_{n}=v_{n-1} \Delta t_{n}+\frac{1}{2} v_{n} \Delta t_{n}-\frac{1}{2} v_{n-1} \Delta t_{n} \Rightarrow \\
\Delta x_{n}=\frac{1}{2}\left(v_{n-1}+v_{n}\right) \Delta t_{n} \Rightarrow \\
x_{n}-x_{n-1}=\frac{1}{2}\left(v_{n-1}+v_{n}\right) \Delta t_{n} \Rightarrow \\
x_{n}=x_{n-1}+\frac{1}{2}\left(v_{n-1}+v_{n}\right) \Delta t_{n} .
\end{gathered}
$$

where $x_{n}, v_{n}, a_{n}-$ position of the train, its speed and acceleration at $n$ step.

For one hour step we have:

$$
x_{t}=x_{t-t \text { step }}+\frac{1}{2}\left(v_{t-t s t e p}+v_{t}\right) \text { tstep },
$$

where $x_{t}$ - final position of the train for one tstep; $x_{t-t s t e p}-$ the initial position of the train for one tstep.

Fig. 1. The typical scheme of traction drive

Output Converter

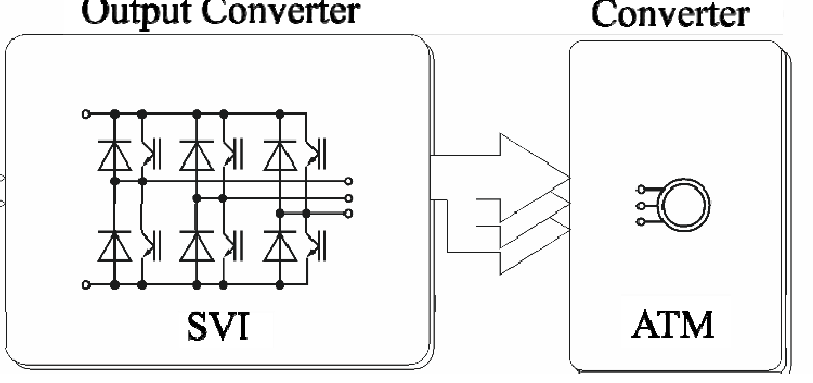




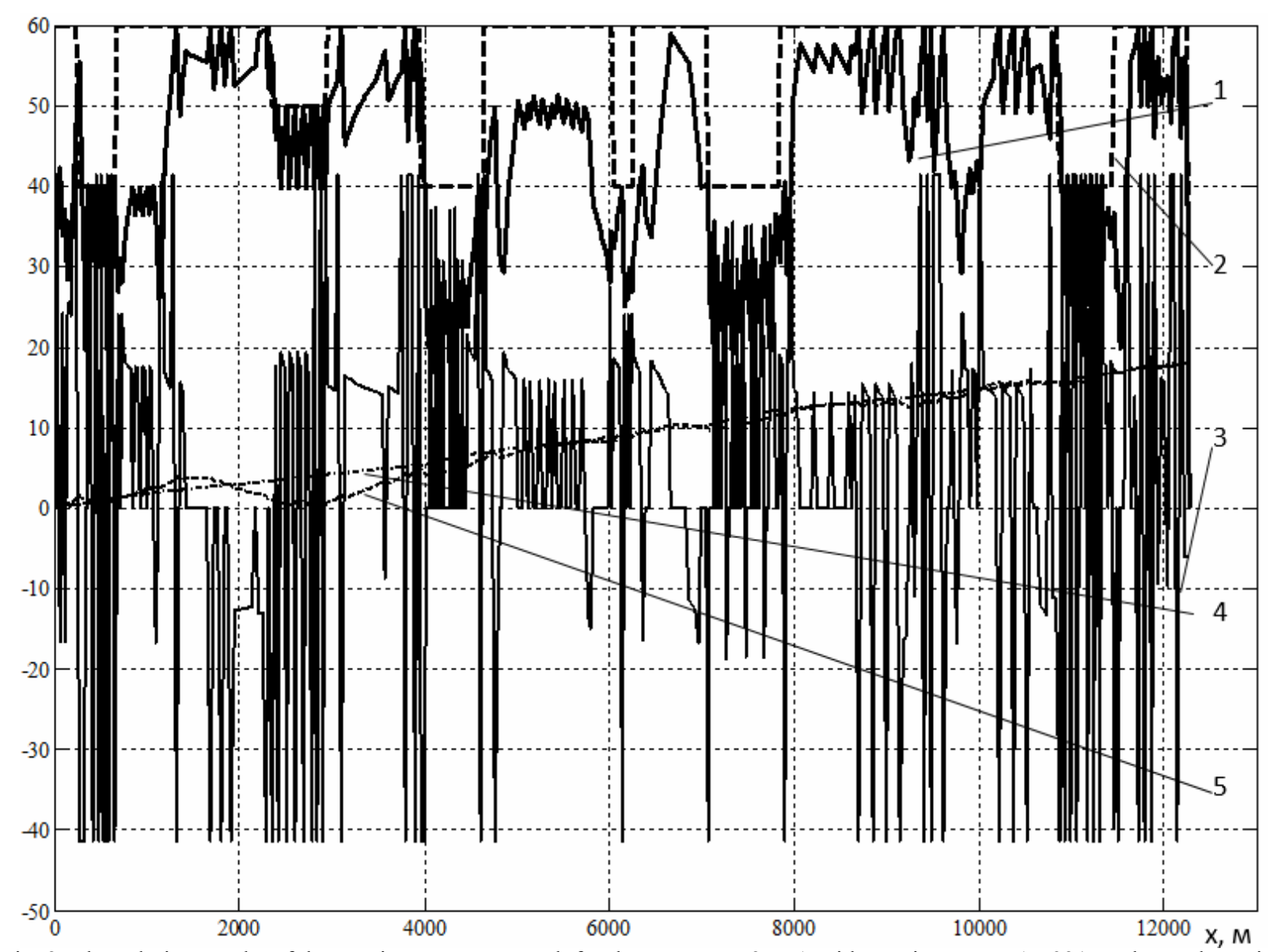

Fig. 2. The solution results of the traction movement task for the tramcar T-3VPA with traction motor AD931 on the track section from the tram depot «Saltovske» to the turning circle of 602 district in Kharkiv and in the reverse direction:

1 - movement speed $(v), \mathrm{km} / \mathrm{h} ; 2$ - speed limitation, $\mathrm{km} / \mathrm{h} ; 3$ - traction force, $\left(F_{r r}\right) \mathrm{kN} ; 4$ - movement time $(t)$, min, 5 -losses $(E)$, kW·h
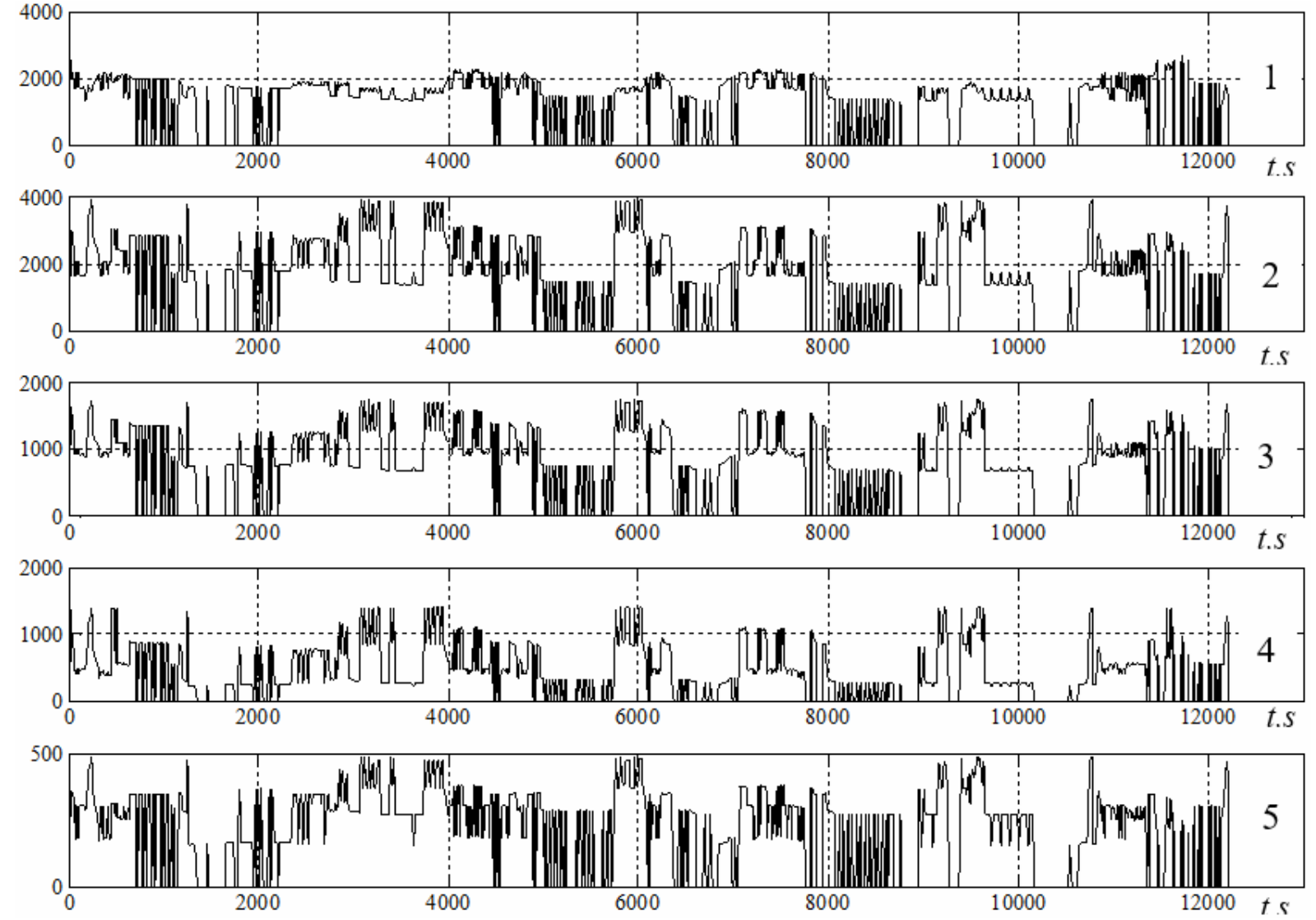

Fig. 3. Loses in traction motor: 1 - core loss $P_{1}, \mathrm{~W} ; 2$ - rotor loss $P_{2}, \mathrm{~W} ; 3$ - copper losses in stator winding at a slot part $P_{3}$, W; 4 - copper losses in stator winding at a front part $P_{4}, \mathrm{~W} ; 5-$ mechanical losses $P_{5}, \mathrm{~W}$ 


\section{Conclusions.}

1. Using the genetic algorithm and the YakobiHamilton-Belman method the calculated ratios for the determination of the railway electromotive traction drive efficiency are obtained. On this base the methodology of ATM motion simulation during the movement of the electromotive rolling stock according to the poweroptimal regimes on the track section with the given graph and the set motion schedule is improved.

2. The adequacy of the obtained equations, which determine the efficiency both the maximum efficiency value of the ATM-SVI circuit in different operating modes under the coupling constraints, and constructive speed, is confirmed by the results of the experiment on the section of the tramway from the depot «Saltovske» to the turning circle of 602 district in Kharkiv. The maximum deviation in the calculation of losses does not exceed $7.42 \%$.

3. According to the results of solved traction problem, the change in losses in the elements of the traction tram traction design was first determined.

4. The use of advanced methodology is proposed to be carried out in advance based on solving the problem of work modes conditional optimization.

\section{REFERENCES}

1. Liubarskiy B.G. Teoretychni osnovy dlya vyboru ta ocinky perspektyvnyh system elektromehanichnogo peretvorennya energiyi elektroruhomogo skladu. Diss. dokt. techn. nauk [The theoretical basis for the selection and evaluation of advanced systems of electromechanical energy conversion of electric rolling stock. Doc. tech. sci. diss.]. Kharkiv, 2014. 368 p. (Ukr).

2. Petrenko O.M., Liubarskiy B.G., Riabov E.S. Investigation of the asynchronous traction motor windings temperature influence on the autonomous inverter voltage operating modes. Electrification of transport, 2016, no.12, pp. 87-91. (Rus).

3. Noskov V.I. Thermal modal traction engine locomotive. Bulletin of NTU «KhPI», 2012, no.62(968), pp. 142-147. (Rus).

4. Kosmodanianskyi A.S. Teoreticheskie osnovy i razrabotka system regulirovanija temperatury tjagovyh elektricheskih mashin lokomotivov. Diss. dokt. techn. nauk [Theoretical foundations and development of temperature control systems for traction electric cars of locomotives. Doc. tech. sci. diss.] Moscow, 2002. 285 p. (Rus).

5. Shcherbatov V.V., Rapoport O.L., Tsukublin A.B. Modeling the thermal state of the traction motor for resource forecasting. Bulletin of the Tomsk Polytechnic University. Geo Assets Engineering, 2005, vol.308, no.7, pp. 156-159. (Rus).

6. Getman G.K. Nauchnye osnovy opredelenija racional'nogo moshhnostnogo rjada tjagovyh sredstv zheleznodorozhnogo transporta [Rolling electrical complex on the basis of the criterion of minimizing the area under the curve of motion] Dnipro, Dnipro National University of Railway Transport named after academician V. Lazaryan Publ., 2008. 444 p. (Rus).
7. Mokin O.B., Mokin B.I. Modelyuvannya ta optymizaciya ruhu bagatomasovyh elektrychnyh transportnyh zasobiv poverhnyamy zi skladnym relyefom [Modeling and optimization of movement of multi-mass electric vehicles with difficult terrain surfaces]. Vinnitsa, VNTU Publ., 2013. 192 p. (Ukr).

8. DmitrienkoV.D., Zakovorotnyi A.Yu. Modelirovanie $i$ optimizacija processov upravlenija dvizheniem dizel'-poezdov [Modeling and optimization of diesel train trains control processes]. Kharkiv, NTMT Publ. Center, 2013. 248 p. (Rus).

9. Petrenko O.M., Liubarskiy B.G. Determination of the efficiency of the electromotive structure. Key points and approaches. Information and control systems on the railway transport, 2015, no.6, pp. 8-13. (Ukr).

10. Todorov E. Optimal control theory. Bayesian Brain: Probabilistic Approaches to Neural Coding, 2006, chap. 12, pp. 268-298. doi: $\mathbf{1 0 . 7 5 5 1 / m i t p r e s s / 9 7 8 0 2 6 2 0 4 2 3 8 3 . 0 0 3 . 0 0 1 2 . ~}$

11. Kappen H.J. Optimal control theory and the linear Bellman equation. Bayesian Time Series Models, 2011, pp. 363-387. doi: 10.1017/cbo9780511984679.018.

12. Kanemoto Y. Theories of urban externalities. Holland, North-Holland Publ., 1980. 189 p.

13. Riabov E.S., Petrenko O.M., Overianova L.V. Analysis of losses in the traction induction motor under various power conditions. Eurasian Union of Scientists, 2016, no.12(33), chapt. 2, pp. 59-65. (Rus).

14. SeverinV.P., Nikulina E.N. Metody odnomernogo poiska [Methods of one-dimensional search]. Kharkiv, NTU KhPI Publ., 2013, 124 p. (Rus).

15. Panagiotis G. Study on optimal train movement for minimum energy consumption. Sweden, School of Innovation, Design and Engineering Publ., 2013. 82 p.

16. Balaji M., Kamaraj V. Design of high torque density and low torque ripple switched reluctance machine using genetic algorithm. European Journal of Scientific Research, 2010, vol.47, no.2, pp. 187-196.

17. Petrenko O.M., Domanskyi O.V., Liubarskiy B.G. Method of rolling stock asynchronous traction drive modes optimization. Mechanics and engineer, 2016, no.1, pp. 59-67. (Ukr).

18. Petrenko O.M., Liubarskiy B.G., Gliebova M.L. Softwareoriented mathematical model of vehicle movement. Bulletin of $N T U$ «KhPI», 2016, no.6(1178), pp. 89-95. (Ukr).

19. Owatchaiphong S., Fuengwarodsakul N.H. Multi-objective based optimization for switched reluctance machines using fuzzy and genetic algorithms. 2009 International Conference on Power Electronics and Drive Systems (PEDS). doi: 10.1109/peds.2009.5385926.

Received 01.10.2017

\section{O. Petrenko ${ }^{1}$, Candidate of Technical Sciences, Associate} Professor.

B. Liubarskiy ${ }^{2}$, Doctor of Technical Sciences, Professor,

V. Pliugin ${ }^{1}$, Doctor of Technical Sciences, Professor,

${ }^{1}$ O.M. Beketov National University of Urban Economy in Kharkiv,

17, Marshal Bazhanov Str., Kharkiv, 61002, Ukraine,

e-mail: petersanya1972@gmail.com

${ }^{2}$ National Technical University «Kharkiv Polytechnic Institute»,

2, Kyrpychova Str., Kharkiv, 61002, Ukraine.

How to cite this article:

Petrenko O., Liubarskiy B., Pliugin V. Determination of railway rolling stock optimal movement modes. Electrical engineering \& electromechanics, 2017, no.6, pp. 27-31. doi: 10.20998/2074-272X.2017.6.04. 